\title{
Urin mot fregner
}

I mange år hadde Tidsskriftet en fast spalte om kvakksalveri. Blant artiklene i 1909 sto et anonymt innlegg (29: 30 -1). Saken var følsom, fordi innsenderen påpekte at en lege opptrådte som kvakksalver i dagspressen.

Den på slutten omtalte legen, Frimann Koren (1865-1927), var ifølge «Norges leger» praktiserende lege i Kristiania. I Fri presse redigerte han spalten «Syg og sund» i et halvt år. I 1908-12 skrev han populærmedisinske artikler i Morgenposten, og i 1911 redigerte han den medisinske del av «Spørgsmaal og svar» i Tidens Tegn.

\section{Læger og kvaksalvere.}

«I en nu salig hensovet avis «Fri presse» for lørdag den 1 ste februar iaar har en herboende læge under rubriken «syk og sund» besvaret endel indkomne forespørsler. Spørsmaal 85 lyder saaledes: Findes noget godt middel mot fregner? Lægen svarer: "Jeg har brukt flere raad, men intet hjælper. Jeg har ogsaa fregner om vinteren. Paa apoteket findes intet middel mot fregner. Derimot er der et godt husraad, som De jo kan forsøke (jeg har talt med paalitelige folk, som har prøvet det paa sig selv med godt resultat). Masser morgen og aften det fregnede parti med litt urin. Dette kan jo gjøres i stilhet, saa ingen vet om det. Ufarlig er denne behandling i ethvert fald.» Dette er altsaa skrevet med fuldt alvor av en eksamineret norsk læge anno 1908. [...]

Jeg har tilslut at meddele, at forfatterne av lægebesvarelserne $\mathrm{i}$ «Fri presse» staar i nævte nummer for 1ste februar navngit som - doktor Frimann Koren.

Kristiania, november 1908. Samler av curiosa.» 